\title{
Cushing's Syndrome Secondary to ACTH-Independent Macronodular Adrenal Hyperplasia
}

\section{atualização}

\author{
Marcia Helena Soares Costa \\ ANDRÉ LACROIX
}

Division of Endocrinology, Department of Medicine, Centre hospitalier de I'Université de Montréal (CHUM), Montréal, Canada.

\begin{abstract}
ACTH-Independent macronodular adrenal hyperplasia (AIMAH) is a rare cause of endogenous Cushing's syndrome (CS), in which clinical features usually become apparent only after several decades of life. This form of adrenal hyperplasia typically produces excess cortisol with overt or subclinical CS, but concurrent secretion of mineralocorticoids or sexual steroids can also occur. The diagnosis is suspected by bilateral adrenal nodules larger than $1 \mathrm{~cm}$ on incidental imaging studies or following the demonstration of ACTH-independent hormonal hypersecretion. The pathophysiology of this entity is heterogeneous and has been intensely explored in recent years. Several G-protein coupled receptors aberrantly expressed in the adrenal cortex have been implicated in the regulation of steroidogenesis and in the initial cell proliferation in AIMAH. Several familial cases of AIMAH have been recently described with the same pattern of aberrant hormone receptors in all affected members of the family. It is probable that additional somatic genetic events related to cell cycle regulation, adhesion and transcription factors occur in addition over time in the various nodules; other mechanisms, as Gsp or ACTH receptor mutations and paracrine adrenal hormonal secretion have been rarely identified as the molecular mechanism in some cases. When systematically screened, most patients with AIMAH exhibit an in vivo aberrant cortisol response to one or various ligands suggesting the presence of aberrant adrenal receptors. The identification of these receptors creates the possibility of a specific pharmacological treatment isolated or associated with adrenalectomy. (Arq Bras Endocrinol Metab 2007;51/8:1226-1237)
\end{abstract}

Keywords: ACTH-independent macronodular adrenal hyperplasia (AIMAH); Aberrant adrenal receptors; Cushing's syndrome

\section{RESUMO}

Síndrome de Cushing Secundária a Hiperplasia Adrenal Macronodular Independente de ACTH.

A hiperplasia adrenal macronodular independente de ACTH (AIMAH) é uma causa rara de síndrome de Cushing (SC) endógena, na qual alguns aspectos clínicos só se tornam evidentes depois de várias décadas de vida. Esta forma de hiperplasia adrenal caracteristicamente produz excesso de cortisol resultando na síndrome de Cushing franca ou subclínica, embora a secreção concomitante de mineralocorticóide, estrógeno e andrógenos também possa ocorrer. A suspeita diagnóstica é feita pela presença de nódulos adrenais bilaterais maiores que $1 \mathrm{~cm}$, como achado incidental em exames de imagem ou pela demonstração de hipersecreção hormonal independente de ACTH. A fisiopatologia desta doença é heterogênea e tem sido intensamente estudada nos últimos anos. Vários receptores acoplados à proteína $\mathrm{G}$, com expressão aberrante no córtex adrenal, têm sido implicados na regulação da esteroidogênese e no início da proliferação celular que ocorre na AIMAH. Diversos casos familiais de AIMAH foram recentemente descritos, e um mesmo padrão de expressão anormal dos receptores aberrantes foi observado em todos os membros afetados das famílias investigadas. Ao longo do tempo, é provável que ocorram, nos nódulos, eventos genéticos adicionais relacionados à regulação do ciclo celular, adesão e fatores de transcrição. Outros mecanismos moleculares, como mutações nos genes da proteína Gs $\alpha$ e do receptor de ACTH, ou secreção hormonal parácrina na adrenal, têm sido raramente identificados em alguns casos. A maioria dos pacientes com AIMAH, quando sistematicamente investigados, desenvolve uma produção anormal de cortisol em resposta a vários ligantes, sugerindo a presença de receptores adrenais aberrantes. A identificação destes receptores cria a possibilidade para um tratamento farmacológico específico isolado ou associado à adrenalectomia. (Arq Bras Endocrinol Metab 2007;51/8:1226-1237)

Descritores: Hiperplasia adrenal macronodular independente de ACTH (AIMAH); Receptores adrenais aberrantes; Síndrome de Cushing
Recebido em 18/07/07 Aceito em 28/07/07 
S INCE ITS DESCRIPTION BY HARVEY Cushing in 1932 (1), the identification of the various pathophysiologies underlying Cushing's syndrome (CS) has increased considerably. Classically, endogenous CS is divided into ACTH-dependent etiologies, most often secondary to a pituitary corticotroph adenoma, and ACTH-independent adrenal etiologies which account for $15-20 \%$ of cases (2). Unilateral functional adenomas and, less frequently, carcinomas are responsible for the majority of adrenal CS; in 10-15\% of cases, adrenal CS is due to bilateral adrenal lesions including primary pigmented nodular adrenocortical disease (PPNAD), primary non-pigmented micronodular hyperplasia, ACTH-independent macronodular adrenal hyperplasia (AIMAH), and rarely bilateral adenomas or carcinomas (2). In a review of literature in 1994, Lieberman et al. (3) were able to find only 24 cases of AIMAH published since its initial description thirty years previously. A much larger number of cases of AIMAH with overt oversecretion or subclinical secretion of cortisol or other steroids have since then been reported. In this review, we will discuss the clinical characteristics of this form of adrenal hyperplasia, its current genetic or molecular aspects and therapy.

\section{ACTH-INDEPENDENT MACRONODULAR ADRENAL HYPERPLASIA (AIMAH)}

AIMAH has been described under a number of terms, including massive macronodular adrenocortical disease (MMAD), autonomous macronodular adrenal hyperplasia (AMAH), ACTH-independent massive bilateral adrenal disease (AIMBAD), and giant or huge macronodular disease (4). This form of adrenal hyperplasia was initially confused with diffuse nodular or bilateral macronodular adrenal hyperplasia resulting from chronic stimulation by ACTH in Cushing's disease or ectopic ACTH secretion (5). AIMAH should be clearly distinguished as an entity in which ACTH becomes progressively suppressed as the primary adrenal enlargement produces sufficient cortisol excess to inhibit the hypothalamic-pituitary axis.

Chronic stimulation by ACTH can induce not only diffuse, but also nodular growth of the adrenal cortex and very rarely one such nodule can secrete sufficient cortisol to suppress ACTH significantly. However the fact that patients with AIMAH did not develop corticotroph adenomas or Nelson's syndrome following bilateral adrenalectomy helped to legitimate AIMAH as an etiology of CS distinct from Cushing's disease and clearly ACTH-independent (6).

\section{Epidemiology}

The majority of cases of AIMAH become clinically manifest during the fifth and sixth decades of life, a later age of onset compared to other causes of Cushing's syndrome. The equal gender distribution also contrasts with the female predominance in most cause of endogenous CS (7). CS with bilateral adrenal nodules can rarely develop during the first years of life in patients with McCune-Albright syndrome (8).

AIMAH was most frequently reported as sporadic cases, but lately, there have been reports of familial forms with apparent autosomal dominant mode of transmission (9-11).

\section{Clinical and laboratory features}

The most frequent presentation of AIMAH is clinical or subclinical Cushing's syndrome. Some cases with secretion of cortisol and mineralocorticoids, cortisol and estrone and androgens only have also been reported (1215). In some patients, the adrenal lesions are found incidentally in the process of radiological investigation of another disease. In these patients, cortisol or other hormones typically do not suppress normally following dexamethasone suppression tests (16). Depending on the extent of cortisol hypersecretion, plasma ACTH and its stimulation by CRH will become progressively suppressed in AIMAH. It is important to be aware that several cases with subclinical CS cannot have completely suppressed their pituitary-adrenal axis. These patients are characterized by the absence of clinical signs of CS, slightly elevated midnight plasma or salivary cortisol, subnormal suppression following the $1 \mathrm{mg}$ overnight dexamethasone suppression test, a partially suppressed ACTH and a normal 24-hour urinary cortisol (16).

Although adrenal cell proliferation in AIMAH occurs in the absence of ACTH, the ACTH receptor gene $(M C 2 R)$ is still expressed in AIMAH tissue and the majority of patients respond to ACTH with large increase of cortisol as a result of the large adrenal cell masserase $(17,18)$. The hormone secretion in AIMAH results from an increase in the number of adrenocortical cells rather than an augmented synthesis per cell; in fact there is a relatively inefficient hormonal synthesis in AIMAH with decreased expression of several steroidogenic enzymes and higher levels of certain precursors such as plasma 17-OH-progesterone or urinary 17-OH corticosteroids (U17OHCS) which are proportionally more elevated than urinary free cortisol $(16,18,19)$.

\section{Radiology}

The adrenal glands can be massively enlarged bilaterally (figure 1) with the presence of numerous nodules 

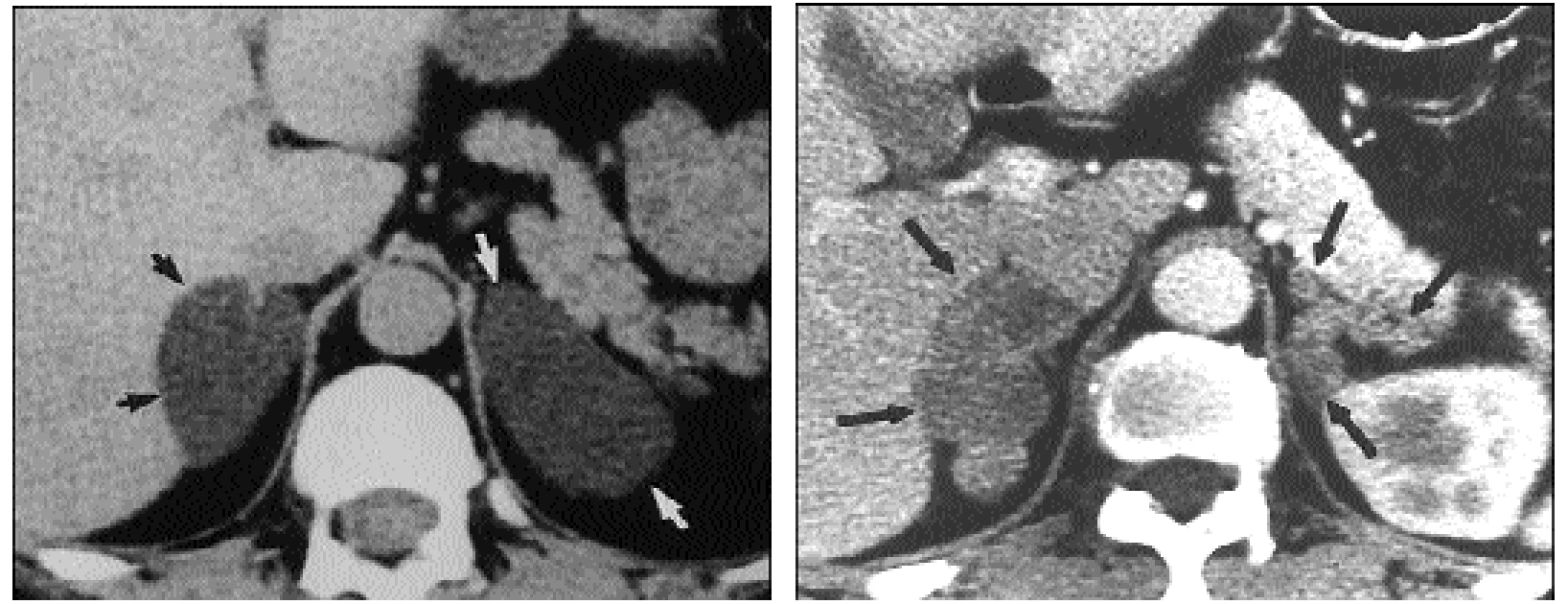

Figure 1. CT scan of a patient with AIMAH with markedly nodular enlargement of both adrenals.
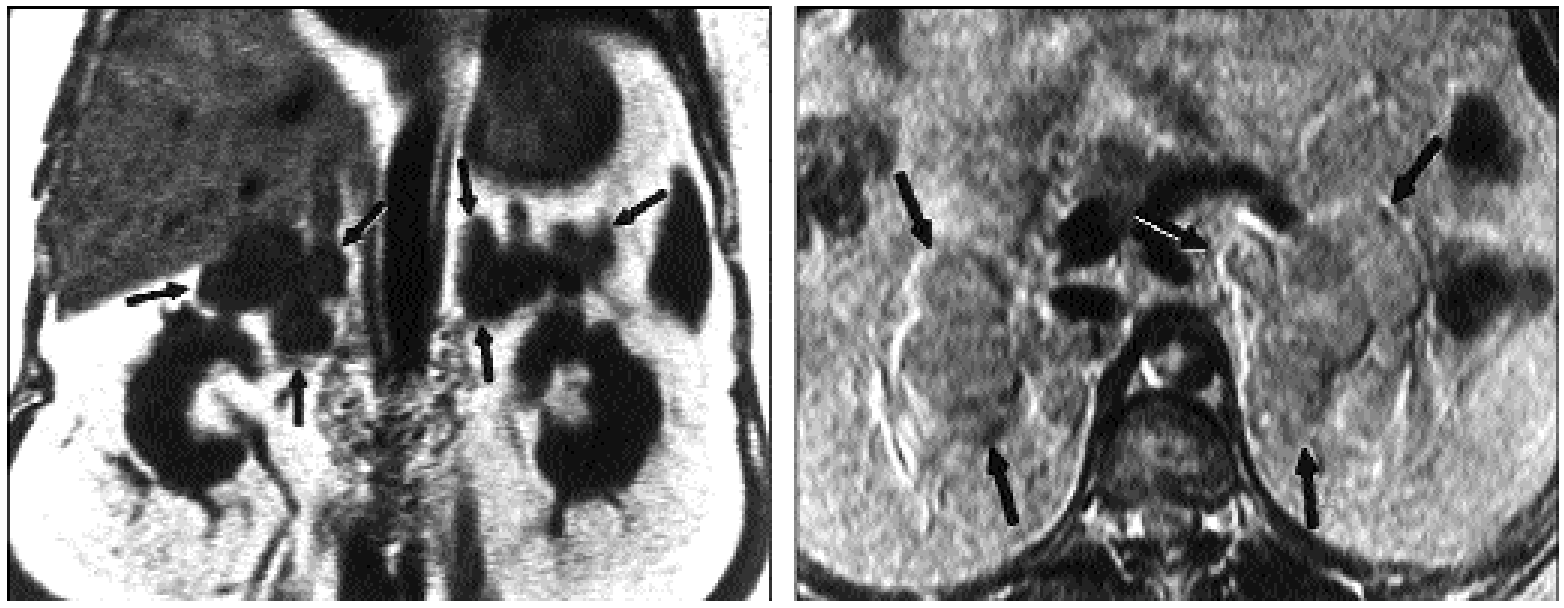

Figure 2. MR imaging of AIMAH adrenal glands with hypointense and isointense signal in T1 and T2-weighted images respectively.

up to $5 \mathrm{~cm}$ in diameter; however, diffuse adrenal enlargement without nodules has also been described (20). On CT, the nodules present hypodensity and can have marked enhancement after contrast imaging. In MR imaging, the glands are isointense relative to spleen and hypointense relative to the liver on $\mathrm{Tl}$-weighted images, and hyperintense relative to both on T2weighted images (figure 2). The glands can demonstrate a signal dropout at chemical shift imaging, suggesting the presence of intracellular lipid (21). Doppman et al. (22) described very similar characteristics in the adrenal glands of 12 patients with AIMAH (three men, nine women) and also found a bilateral uptake of Iodine-131-6ß-iodomethyl-19-norcholesterol (NP59). The asymmetric appearance of adrenal macronodules in AIMAH has been described and may lead to the erroneous diagnosis of unilateral pathology as the development of contralateral disease can occur several years later $(4,23)$.

\section{Pathology}

The combined mean weight of adrenal gland in AIMAH is usually above $60 \mathrm{~g}$ and can reach more than $200 \mathrm{~g}$ per adrenal $(3,7)$. In contrast, the combined adrenal weight in patients with ACTH-dependent Cushing's disease is more modest reaching on average less than $30 \mathrm{~g}(24)$. The nodules are yellow in coloration, without dark pigmentation; they are composed of two types of cells, those with clear cytoplasm (lipidrich) that forms cordon-like structures and those with compact cytoplasm (lipid-poor) that forms nest or island-like structures $(25,26)$. The status of internodu- 

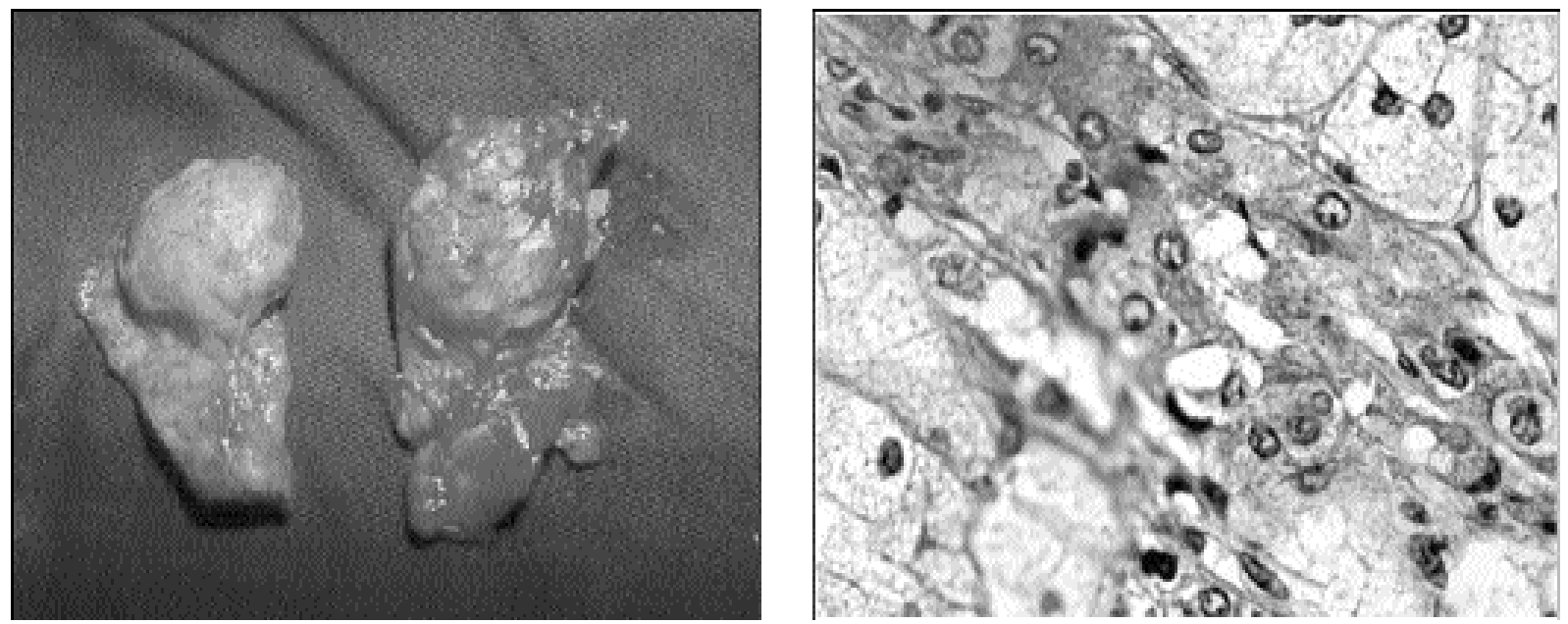

Figure 3. Macroscopic and microscopic images of a very large adrenal gland from a patient with AIMAH. There are multiple nodules with sizes up to $5 \mathrm{~cm}$.

lar cortex is controversial in AIMAH; diffuse hyperplasia is present in several cases while inter-nodular atrophy has been described in other cases $(6,25,27,28)$ (figure $3)$. The inefficient hormonogenesis in AIMAH is probably the result of altered steroidogenic enzymatic pathways of the two types of cells that compose the nodules. Immunohistochemical studies demonstrated that $3 \beta$ HSD2 was expressed only in large clear cells, whereas CYP17 (p450Cl7) was expressed predominantly in small compact cells. This differential pattern of steroidogenic enzyme expression is distinctive of AIMAH and is not present in other adrenocortical disease (26). Immunoreactivity for CYP1IAl, CYP21A2, and CYP11B2 demonstrate their presence in both cell types, at decreased level, also contributing to inefficiency of steroid synthesis.

\section{Pathophysiology}

\section{Aberrant hormone receptors}

The regulation of cortisol hypersecretion in AIMAH when ACTH is suppressed has been clarified in recent years. In the past, steroid production in this disease was believed to be autonomous. There are now several evidences that steroidogenesis in AIMAH is regulated by hormones other than ACTH as a result of the aberrant expression of their respective receptors in adrenocortical tissue; this is the most prevalent pathophysiology in patients with AIMAH.

This concept was first introduced by Ney and colleagues (29), who demonstrated in vitro that cAMP and corticosterone production in rat adrenocortical carcinoma cells were stimulated by non- ACTH hormones, such as catecholamines, TSH, FSH, LH, and prostaglandin El. This hypothesis was later validated in humans by additional in vitro and in vivo studies $(2,30)$. It has been established that the aberrant stimulation of steroidogenesis in AIMAH and in some unilateral adenomas can be driven by ectopic receptors such as those for glucose-dependent insulinotropic peptide or gastric inhibitory polypeptide (GIPR), $\beta$ adrenergic receptors, vasopressin $\left(\mathrm{V}_{2}-\mathrm{V}_{3}\right.$-vasopressin receptor), serotonin (5- $\mathrm{HT}_{7}$ receptor), and probably angiotensin II receptor (ATlR); it can also result from increased expression or altered activity of eutopic receptors such as those for vasopressin $\left(\mathrm{V}_{1}\right.$-vasopressin receptor), luteinizing hormone/human chorionic gonadotropin (LH/hCGR), serotonin $\left(5-\mathrm{HT}_{4}\right.$ receptor), and leptin receptor (2). Analysis of the second messengers involved indicates that these aberrant Gprotein coupled receptors (GPCRs) regulate steroidogenesis by mimicking the cellular events that are triggered normally by ACTH receptor (figure 4) (30).

\section{GIP-responsive CS}

The first case of food-dependent cortisol production was identified in a 41-yr-old male patient with Cushing's syndrome secondary to a unilateral adenoma. This patient presented low plasma cortisol in the morning or during fasting, but it increased after meals, despite suppression by high doses of dexamethasone (31). Five years later, in vivo and in vitro studies performed by two independent groups allowed to identify the mechanisms of the food-dependent hypercortisolism; in both patients with AIMAH, it was demonstrated that cortisol increased following postprandial physiological increase in plasma level of GIP, suggesting the ectopic adrenal expression of GIP receptor $(32,33)$. 


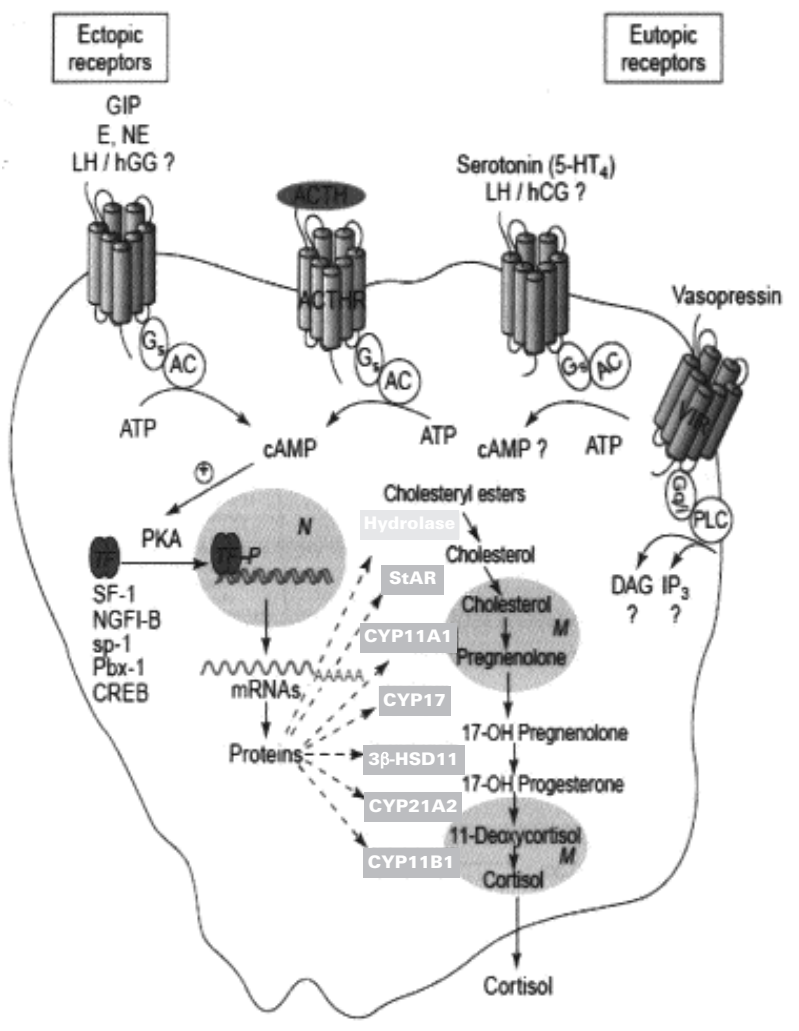

Figure 4. Regulation of steroidogenesis by aberrant hormone receptors in adrenal cortex; in this model, the receptors regulate steroidogenesis by mimicking the cellular events triggered by ACTH receptors activation. [Adapted from ref. 30]

GIP is a gastrointestinal hormone released in physiological concentrations by $\mathrm{K}$ cells from duodenum and small intestine after food ingestion (2). The suspicion that cortisol production could be regulated by a gastrointestinal hormone came from the observation that plasma cortisol was stimulated by oral administration of glucose or by lipid-rich or protein-rich meals, but not by intravenous glucose. The presence of GIP receptor was further confirmed by adrenal imaging following the injection of [123I]-GIP (32). To date, more than 30 cases, the majority in AIMAH, were reported in whom adrenal hormonal hypersecretion (clinical or subclinical CS, androgen secretion resulting in hirsutism, and primary aldosteronism) was associated to GIP stimulation (30-37). GIPR was overexpressed in GIP-dependent tissues compared with normal fetal or adult adrenal gland $(23,34,36)$. In vitro experiments have demonstrated that GIP increases cAMP production and DNA synthesis in GIP-dependent cortisol-secreting tissue suggesting that GIP can be implicated both in steroidogenesis and cellular proliferation (38). The mechanisms involved in the aberrant expression of this receptor remain unclear.
Swords et al. (39) suggested that chronic stimulation by ACTH could result in increased GIPR expression, but other studies did not confirm GIPR overexpression in the adrenal gland of patients with Cushing's disease or ectopic ACTH syndrome and even reported a partial repression of ACTH receptor $(18,38,40,41)$.

\section{Vasopressin-responsive AIMAH}

Patients with ACTH-independent CS, in contrast to those with Cushing's disease, do not usually increase plasma cortisol following administration of lysinevasopressin (LVP). However, ACTH-independent stimulation of cortisol following administration or arginine- or lysine-vasopressin has been reported in several patients with either unilateral adenoma or AIMAH and CS who increase their plasma cortisol with upright posture and other physiological stimuli of endogenous vasopressin (2,42-47). As pharmacological levels of AVP can stimulate catecholamine secretion and cortisol production indirectly in patients with ectopic adrenal $\beta$-adrenergic receptors, it is important to demonstrate that the cortisol production is modulated by endogenous vasopressin through water and hypertonic sodium loading $(42,44)$.

In most patients, cortisol secretion was regulated by the non-mutated Vl-vasopressin receptor expressed either at higher or similar levels in the adrenal tissues of vasopressin-responsive AIMAH patients compared to normal individuals. The Vl-vasopressin receptor is normally expressed in the adrenal cortex and stimulates steroidogenesis modestly in vitro, but this is not detectable in vivo; because of this, it has been proposed that the exaggerated steroidogenic response in these patients represents an increased response via an eutopic receptor, as a result of receptor over-expression and/or more efficient receptor coupling to intracellular steroidogenic pathways $(2,45,46)$. Recently, ectopic expression of V2- and V3-vasopressin receptors was reported in vitro in some AIMAH cases, but the effect of dDAVP, a preferential agonist of V2 receptors, was not studied or did not elicit cortisol response in vivo $(47,48)$.

\section{Catecholamine-responsive AIMAH}

In human adrenal glands, catecholamine has a direct modulator effect on aldosterone, but not on cortisol secretion. The aberrant adrenal expression of $\beta$-adrenergic receptors was first reported in a patient with AIMAH and CS whose cortisol and aldosterone secretion increased in response to endogenous changes in catecholamine levels (upright posture, insulin induced hypoglycemia or exercise) (42). The infusion of iso- 
proterenol, a $\beta$-agonist, stimulated both cortisol and aldosterone secretion in this patient, but not in normal subjects (42). Similar findings were reported in other patients with AIMAH $(44,49,50)$. In vitro studies have revealed that the adrenal tissue of such patients, but not in normal controls, present high-affinity binding sites compatible with $\beta 1$ and $\beta 2$ adrenergic receptors that are efficiently coupled to steroidogenesis, indicating the ectopic nature of this receptor $(44,49,50)$. The combined presence of aberrant Vlvasopressin with $\beta$-adrenergic receptor or with 5$\mathrm{HT}_{4} \mathrm{R}$ have been described in sporadic and familial cases of AIMAH $(16,44,48-50)$.

\section{LH/hCG-responsive AIMAH}

The luteinizing hormone receptor (LH/hCGR) is mainly involved in the regulation of ovarian and testicular functions (51). A wide $L H / h C G R$ expression pattern has been demonstrated in several human fetal tissues, including adrenal cortex, kidney, liver, pancreas, lung, small and large intestines (52). In the normal adrenal cortex, it is expressed in the zona reticularis and hCG stimulates the production of dehydroepiandrosterone sulfate in fetal but not in adult adrenal cells $(53,54)$.

The aberrant adrenal function of $\mathrm{LH} / \mathrm{hCG}$ receptor was first identified in a woman with transient CS during sequential pregnancies; persistent CS and AIMAH developed only after the post-menopausal sustained elevation of endogenous LH (55). Administration of the long-standing GnRH analog leuprolide acetate led to suppression of endogenous $\mathrm{LH}$ and normalization of cortisol production (55). The $L H / h C G R$ was present in a non-mutated form and its expression was not increased compared with normal adrenal tissue. In the same patient, cisapride and metoclopramide, two serotonin $5-\mathrm{HT}_{4}$ receptor agonists also stimulated plasma cortisol (55). Some cases of aberrant receptors for $\mathrm{LH} / \mathrm{hCG}$ in combination with serotonin or other receptors have been reported $(16,56,57)$. A 59 -yr-old virilized woman with androgen-secreting AIMAH regulated by hCG was shown to express the LH/hCGR in one resected adrenal; suppression of endogenous LH with leuprolide acetate normalized androgen secretion from the contralateral adrenal, avoiding bilateral adrenalectomy (15).

\section{Serotonin-responsive AIMAH}

In the normal adrenal gland, $5-\mathrm{HT}_{4}$ receptor agonists are potent stimulators of aldosterone secretion but only weakly affect cortisol secretion in vitro. In vivo, they normally do not produce an increase in plasma cortisol.
After the first description of combined aberrant $\mathrm{LH}$ and serotonin 5- $\mathrm{HT}_{4}$ receptors in AIMAH, several patients were identified with an increased cortisol secretion after cisapride, metoclopramide or tegaserod stimulation $(16,48,56-60)$. In six patients with AIMAH and aberrant response to cisapride or metoclopramide, adrenal overexpression of $5 \mathrm{HT}_{4}$ receptor was found in four patients. In the two of these patients with normal levels of this receptor, the molecular mechanism of the aberrant response remains unclear, and no differences in splice variants or in the cDNA sequence of the receptor were identified (58). More recently, the ectopic expression and function of $5 \mathrm{HT}_{7}$ receptor was identified in a patient with serotoninresponsive AIMAH and Cushing's syndrome (60).

\section{Angiotensin-responsive AIMAH}

In a patient with AIMAH and an increased plasma secretion of aldosterone and cortisol after upright posture, the possibility of response to angiotensin II was confirmed following the normalization of hormonal secretion by an oral short-term administration of candesartan, an AT-1 receptor antagonist (61). Chronic treatment of the patient with an AT-1 receptor antagonist was not attempted and no in vitro demonstration of the presence of this receptor was provided (61). In vitro stimulation of cortisol secretion by angiotensin II also occurred in patients with AIMAH and CS who had increases in cortisol levels with upright posture (57).

\section{Other abnormal responses in AIMAH}

Several in vitro studies further support the expression of other GPCRs in AIMAH. Leptin synthesis is stimulated by glucocorticoids and this hormone normally inhibits cortisol secretion in the adrenal gland (62-64). In a patient with AIMAH and CS, GIP and leptin were shown to aberrantly increase cortisol production in vitro. The GIP and leptin receptors were not measured directly in this case (65). These responses have never been demonstrated in vivo. Two patients with AIMAH and CS have had insulin-induced hypoglycemia stimulated cortisol production while ACTH levels remained suppressed $(66,67)$. In vitro adrenal cortisol secretion was not stimulated by insulin, catecholamines, vasopressin or angiotensin II (66). Some other in vitro studies have suggested the expression of thyrotropin, FSH, and IL-1 in adrenal benign and malignant lesions $(2,30,68)$.

\section{Molecular mechanisms of aberrant receptors}

The molecular mechanisms leading to the abnormal expression of eutopic and ectopic receptors in the adrenal glands of patients with AIMAH and less com- 
monly in adrenal adenomas remains incompletely understood. The hormonal regulation of the development and function of the adrenal cortex requires tissue-specific expression of appropriate hormone receptors and regulatory mechanisms for these receptors, involving cis-acting regulatory elements (promoters) and trans-acting factors (transcription factors, co-activators and co-repressors) (30). The GIPR is the more extensively characterized ectopic receptor in the adrenal CS. GIPR gene sequence analysis did not reveal mutations of coding or putative promoters regions in adrenals of patients with GIP-dependent CS and the analysis of transcription factors (Spl and Sp3) necessary to GIPR expression also did not show any specific abnormalities $(40,69,70)$.

Expression profiling of AIMAH using DNA microarrays have been utilized to identify genes and signaling pathways potentially involved in this adrenal disease. Bourdeau et al. (71) studied more than 10,000 oncogenesis-related genes in eight AIMAH samples; eighty-two and 31 genes were found to be consistently up- (those implicating in transcription, cell cycle, and adhesion) and down-regulated (genes involved in immune responses and insulin signaling) compared with normal adrenal glands. Lampron et al. (41) confirmed the results previously reported in GIPdependent cortisol producing AIMAH and adrenal tumors, reinforcing the possible role to the WNT pathway of cellular proliferation and adhesion.

It was unclear whether aberrant hormone receptors are a primary phenomenon responsible for the pathogenesis of AIMAH or adenomas, or an epiphenomenon resulting from cell proliferation and dedifferentiation; there are now several evidences in favor of the former hypothesis. The reversal of hyperplasia between pregnancies in LH/hCG dependent CS favors the first hypothesis $(2,30)$. The germline transmission of the same aberrant receptors in all affected family members in familial AIMAH is another strong indication in favor of an initiating role of the aberrant receptor (47-49,72). The demonstration that bovine adrenocortical cells transfected with the GIPR or LH/hCGR and injected under the renal capsule in immunodeficient mice lead to the development of hyperplastic adrenals and hypercortisolism further supports the initiation role of the ectopic receptor in pathophysiology of AIMAH (73-75).

\section{Investigation protocol for aberrant receptors}

Investigative protocols to screen patients with adrenal CS for aberrant receptors have been developed $(76,77)$. The strategy consists of modulating the plasma levels of diverse hormones (endogenous or exoge- nous) or pharmacologic receptor ligands while monitoring plasma levels of cortisol, other steroid hormones and ACTH (under dexamethasone suppression in sub-clinical CS to guarantee no interference of ACTH fluctuation).

All tests are performed following an overnight fast and in a supine position for at least $\mathrm{lh}$. The initial screening (76) is performed in 3 days and involves during the first day a posture test to screen for receptors to angiotensin II, vasopressin, catecholamines or atrial natriuretic peptides; a standard mixed meal to assess the presence of GIP or other gastrointestinal hormone receptors; and cosyntropin test (ACTH 250 $\mu \mathrm{g}$ IV). During the second day, the administration of GnRH $100 \mu \mathrm{g}$ IV evaluates responses to LHRH, LH, and FSH; TRH $200 \mu \mathrm{g}$ IV screens for modulation by THR, TSH or prolactin; on the last day, the protocol is completed with the sequential administration of glucagon $1 \mathrm{mg}$ IM; vasopressin 10 UI IM and $10 \mathrm{mg}$ metoclopramide as a serotonin $5-\mathrm{HT}_{4}$ agonist. Serial measurements of ACTH, cortisol, and other steroid hormones are performed at 30 to $60 \mathrm{~min}$ intervals during $2-3 \mathrm{~h}$ following the intervention. The increment of $25-49 \%$ from the baseline of the steroid levels in the absence of an increase in ACTH level is defined as a partial response and an increase more than $50 \%$ or greater is considered a positive response; the test should be repeated to confirm the response to the specific ligand and its reproducibility. Fluctuations of the putative ligand hormones of interest are also measured to better characterize the modulator of the response. When a positive response following this initial screening is confirmed, further stimulatory test should be undertaken to precisely define the hormone and the specific receptor type implicated (figure 5).

\section{Familial forms and other mechanisms in regulation of hormonal hypersecretion in AIMAH}

Initially reported cases of AIMAH appeared to be sporadic; more recently, first-degree relatives screening identified several familial cases with an autosomal dominant pattern of transmission. AIMAH is also rarely associated with syndromes in which genetic defects have been identified, such as MENl (multiple endocrine neoplasia type 1- menin), familial adenomatous polyposis and hereditary leiomyomatosis (APC), and renal cell cancer disorder (fumarate hydratase) (19,78). Athough PRKARIA mutations were not found in AIMAH, somatic losses of the 17q22-24 region, PKA subunit, and enzymatic activity changes show that PKA signaling is altered in AIMAH in a very similar way of other 

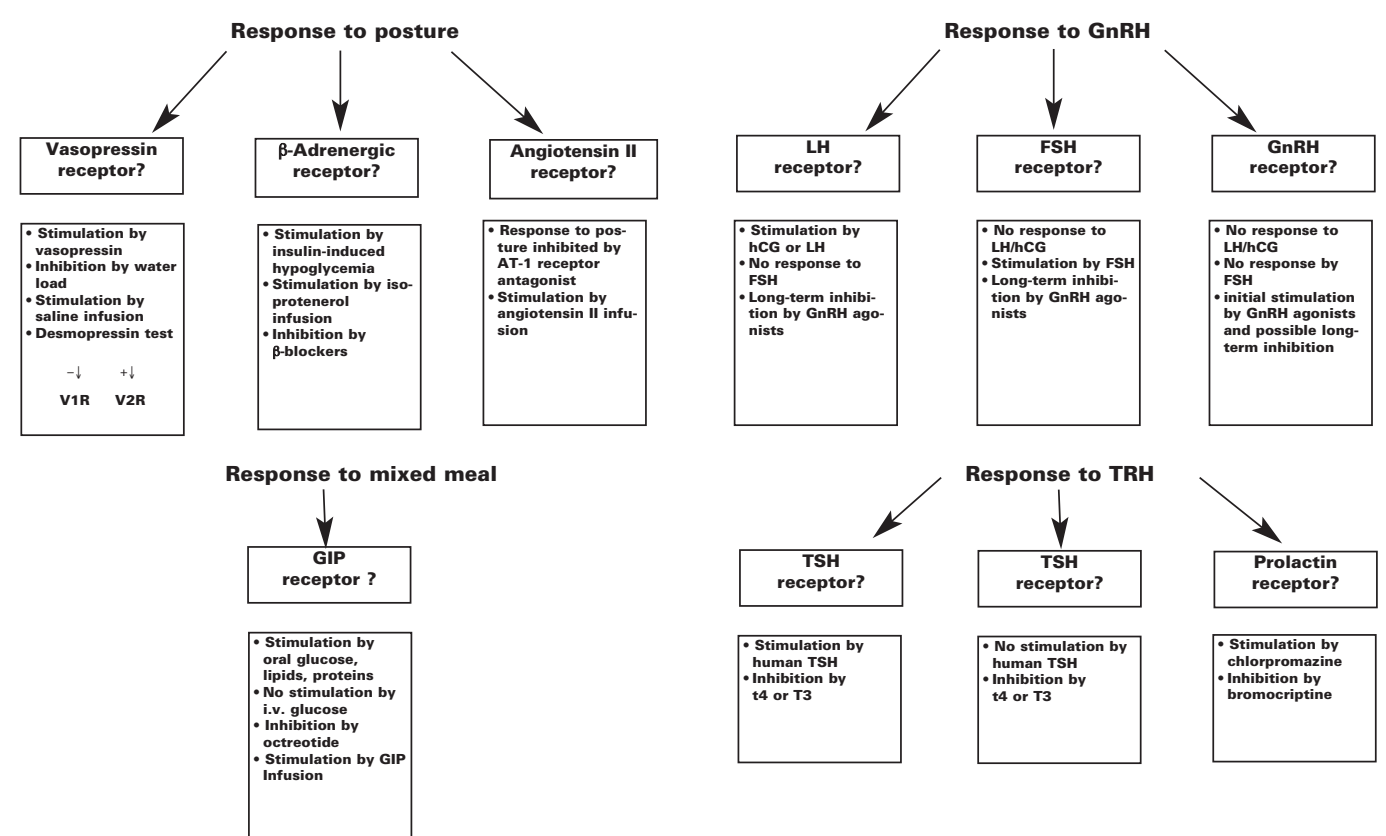

Figure 5. Further in vivo characterization of aberrant adrenal hormone receptors following the initial screening protocol. [Adapted from ref. 76]

adrenal tumors (79). Recently, one of the two familial AIMAH cases was a carrier of a variation $(\mathrm{R} 867 \mathrm{G})$ in the gene (PDE11A) that codified the phosphodiesterase 11 A4 implicated in the regulation of cyclic nucleotide levels (19). AIMAH is found in a subgroup of patients with McCune-Albright syndrome, in which activating mutations of the Gs $\alpha$ subunit occur in the adrenal gland during embryogenesis and conduct to constitutive activation of the cAMP signaling and Cushing's syndrome (7). Fragoso et al. (80) identified Gsa mutations in three of five patients with AIMAH and Cushing's syndrome, without any manifestations of McCuneAlbright syndrome. In a patient with AIMAH, an ACTH receptor mutation was identified, which led to impaired desensitization and internalization of the receptor associated to apparent constitutive activity (81). Two mutations in the same allele of ACTH receptor $(\mathrm{MC} 2 \mathrm{R})$ were also identified in a patient with clinical hypersensitivity to ACTH (82).

In the familial cases of AIMAH without other diseases, the potential presence of aberrant receptors was evaluated only in the recently studied families. Some aberrant receptors have been identified so far: Vl-vasopressin and $\beta$-adrenergic in one family (49); $\beta$ adrenergic in a second one (83); Vl-V2 and V3-vasopressin in another family (47), and combined $5 \mathrm{HT}_{4}$ and V1-V2-vasopressin in another one (48). A systematic clinical screening of a family with hereditary cortisol-secreting $\beta$-adrenergic responsive AIMAH re- vealed unsuspected subclinical Cushing's syndrome and aberrant $\beta$-adrenergic regulation of cortisol in all familial cases studied with subclinical CS (72).

In addition to the aberrant hormone receptors, another paracrine regulatory mechanisms was proposed in some AIMAH cases after the demonstration of increased adrenocortical expression of pro-opiomelanocortin/ACTH, serotonin or vasopressin in affected adrenal tissues $(57,84)$. It is thus interesting to note that AIMAH is a disease with a genetic and molecular heterogeneity, where different mechanisms can potentially contribute together to the final phenotype.

\section{Management of AIMAH}

The bilateral adrenalectomy by overt or laparoscopic approach has been the most useful treatment in patients with AIMAH and hormonal hypersecretion $(3,4,6$, $7,12)$. However, in patients with moderately increased hormonal production, unilateral adrenalectomy has been proposed as a safe and effective alternative; it is expected that, as the cell mass increases in the contralateral adrenal, a second adrenalectomy may be further necessary $(85,86)$. In patients with subclinical AIMAH, the decision for therapy should consider the manifestation of cortisol excess, such as hypertension, diabetes, osteoporosis, apparent brain atrophy or neuropsychological manifestations. Medical treatment with adrenal enzyme inhibitors could be helpful to control cortisol secretion before surgery (7). AIMAH is a benign process that has 
never been shown to become malignant; in sub-clinical CS with AIMAH, follow up with annual CT scan and biochemical assessment is sufficient.

The identification of aberrant adrenal hormone receptors in AIMAH provides new opportunities for specific pharmacological therapies as alternative to adrenalectomy. Pharmacological blockade of postprandial release of GIP using octreotide led to clinical and biochemical improvement of Cushing's syndrome, although without persistent effect probably as the result of eventual desensitization of somatostatin-receptors in GIP-secreting duodenal $\mathrm{K}$ cells $(33,87)$. In catecholamine-dependent CS in AIMAH, $\beta$-adrenergic receptor antagonists were efficient in the long-term control of hormonal hypersecretion $(42,72)$. In LH/hCG-dependent AIMAH and CS, suppression of endogenous LH levels with long-acting leuprolide acetate controlled steroid secretion and avoided bilateral adrenalectomy $(15,55)$. It is possible that tumor regression might not occur, despite complete blockade of the aberrant receptors, because other genetic events (other than aberrant receptors) inducing proliferation can appear over time $(30,41)$.

Based in current studies, it is recommended that all patients with AIMAH and clinical or subclinical Cushing's syndrome undergo screening for aberrant receptors, because this may change the therapeutic strategy. In addition, systematic screening of familial members above 25-30 years old should be conducted with $\mathrm{l} \mathrm{mg}$ overnight dexamethasone tests. Those who do not suppress their plasma cortisol on the following morning under $1.8 \mu \mathrm{g} / \mathrm{dl}(50 \mathrm{nmol} / \mathrm{L})$ should have an adrenal CT scan.

\section{CONCLUSION}

In recent years, several new findings have contributed to a better understanding of the heterogeneity of pathogenesis in AIMAH. Aberrantly expressed G-protein-coupled receptors in the adrenal cortex appear to play a central role in the hormonal hypersecretion and cell proliferation in this disease. However, other molecular mechanisms, as Gsp or ACTH receptor mutations, and adrenal paracrine hormonal secretion can also be implicated in this disease. Together, these studies have contributed to a more precise evaluation of patients with AIMAH, improving earlier diagnosis and offering new therapeutic and potentially preventive strategies.

\section{ACKNOWLEDGMENTS}

This work was supported by grant MT-13-189 from Canadian Institutes of Health Research. Marcia Helena Soares Costa's doctoral fellowship was supported by Fundação de Amparo à Pesquisa do Estado de São Paulo (FAPESP), grant 03/07449-1; her current address is at the Endocrinology Department (Laboratório de Hormônios e Genética Molecular LIM/42) of São Paulo University (USP) in Brazil.

\section{REFERENCES}

1. Cushing $\mathrm{H}$. The Basophil adenomas of the pituitary body and their clinical manifestations. Bull John Hopkins Hosp 1932;50:137-95.

2. Lacroix A, Ndiaye N, Tremblay J, Hamet P. Ectopic and abnormal hormone receptors in adrenal Cushing's syndrome. Endocr Rev 2001;22:75-110.

3. Lieberman SA, Eccleshall TR, Feldman D. ACTH-independent massive bilateral adrenal disease (AIMBAD): a subtype of Cushing's syndrome with major diagnostic and therapeutic implications. Eur J Endocrinol 1994;131:67-73.

4. Stratakis CA, Kirschner LS. Clinical and genetic analysis of primary bilateral adrenal diseases (micro- and macronodular disease) leading to Cushing syndrome. Horm Metab Res 1998;30:456-63.

5. Doppman JL, Miller DL, Dwyer AJ, Loughlin T, Nieman L, Cutler GB, et al. Macronodular adrenal hyperplasia in Cushing disease. Radiology 1988;166:347-52.

6. Swain JM, Grant CS, Schlinkert RT, Thompson GB, vanHeerden JA, Lloyd RV, et al. Corticotropin-independent macronodular adrenal hyperplasia: a clinicopathologic correlation. Arch Surg 1998;133:541-5; discussion 545-6.

7. Malchoff CD MD, Malchoff DM. Adrenocorticotropic hormone-independent adrenal hyperplasia. Endocrinologist 1996;6:79-85.

8. Kirk JM, Brain CE, Carson DJ, Hyde JC, Grant DB. Cushing's syndrome caused by nodular adrenal hyperplasia in children with McCune-Albright syndrome. J Pediatr 1999;134:789-92.

9. Findlay JC, Sheeler LR, Engeland WC, Aron DC. Familial adrenocorticotropin-independent Cushing's syndrome with bilateral macronodular adrenal hyperplasia. J Clin Endocrinol Metab 1993;76:189-91.

10. Minami S, Sugihara H, Sato J, Tatsukuchi A, Sugisaki $Y$, Sasano $H$, et al. ACTH independent Cushing's syndrome occurring in siblings. Clin Endocrinol (Oxf) 1996;44:483-8.

11. Nies C, Bartsch DK, Ehlenz K, Wild A, Langer P, Fleischhacker $\mathrm{S}$, et al. Familial ACTH-independent Cushing's syndrome with bilateral macronodular adrenal hyperplasia clinically affecting only female family members. Exp Clin Endocrinol Diabetes 2002;110:277-83.

12. Malchoff CD, Rosa J, DeBold CR, Kozol RA, Ramsby GR, Page $\mathrm{DL}$, et al. Adrenocorticotropin-independent bilateral macronodular adrenal hyperplasia: an unusual cause of Cushing's syndrome. J Clin Endocrinol Metab 1989;68:855-60.

13. Yamada Y, Sakaguchi K, Inoue T, Kubo M, Fushimi H, Sekii K, et al. Preclinical Cushing's syndrome due to adrenocorticotropin-independent bilateral adrenocortical macronodular hyperplasia with concurrent excess of gluco- and mineralocorticoids. Intern Med 1997;36:628-32.

14. Hayashi Y, Takeda Y, Kaneko K, Koyama H, Aiba M, Ikeda U, et al. A case of Cushing's syndrome due to ACTH-independent bilateral macronodular hyperplasia associated with excessive secretion of mineralocorticoids. Endocr $J$ 1998;45:485-91. 
15. Goodarzi MO, Dawson DW, Li X, Lei Z, Shintaku P, Rao CV, et al. Virilization in bilateral macronodular adrenal hyperplasia controlled by luteinizing hormone. J Clin Endocrinol Metab 2003;88:73-7.

16. Bourdeau I, $D^{\prime}$ Amour $P$, Hamet $P$, Boutin JM, Lacroix A. Aberrant membrane hormone receptors in incidentally discovered bilateral macronodular adrenal hyperplasia with subclinical Cushing's syndrome. J Clin Endocrinol Metab 2001;86: 5534-40.

17. Cheitlin RA, Westphal M, Cabrera CM, Fujii DK, Snyder J, Fitzgerald PA. Cushing's syndrome due to bilateral adrenal macronodular hyperplasia with undetectable ACTH: cell culture of adenoma cells on extracellular matrix. Horm Res 1988;29:162-7.

18. Antonini SR, Baldacchino V, Tremblay J, Hamet $P$, Lacroix A. Expression of ACTH receptor pathway genes in glucosedependent insulinotrophic peptide (GIP)-dependent Cushing's syndrome. Clin Endocrinol (Oxf) 2006;64:29-36.

19. Hsiao HP, Verma S, Boikos SA, Bourdeau I, Kirschner LS, Keil MF, et al. A Molecular and clinical genetic investigation of ACTH-independent macronodular adrenal hyperplasia compared to other, common adrenocortical tumors: Evidence for heterogeneity, overlap with other tumor syndromes and frequent but atypical hormonal secretion. Program of the 89th Annual Meeting of the Endocrine Society, Toronto, CA, 2007, p. 403 (Abstract P2-299).

20. Doppman JL, Nieman LK, Travis WD, Miller DL, Cutler GB, Jr., Chrousos GP, et al. CT and MR imaging of massive macronodular adrenocortical disease: a rare cause of autonomous primary adrenal hypercortisolism. J Comput Assist Tomogr 1991;15:773-9.

21. Rockall AG, Babar SA, Sohaib SA, Isidori AM, Diaz-Cano S, Monson JP, et al. CT and MR imaging of the adrenal glands in ACTH-independent Cushing syndrome. Radiographics 2004;24:435-52.

22. Doppman JL, Chrousos GP, Papanicolaou DA, Stratakis CA, Alexander HR, Nieman LK. Adrenocorticotropin-independent macronodular adrenal hyperplasia: an uncommon cause of primary adrenal hypercortisolism. Radiology 2000;216: 797-802.

23. N'Diaye N, Hamet P, Tremblay J, Boutin JM, Gaboury L, Lacroix A. Asynchronous development of bilateral nodular adrenal hyperplasia in gastric inhibitory polypeptide-dependent Cushing's syndrome. J Clin Endocrinol Metab 1999;84:2616-22.

24. Smals AG, Pieters GF, van Haelst UJ, Kloppenborg PW. Macronodular adrenocortical hyperplasia in long-standing Cushing's disease. J Clin Endocrinol Metab 1984;58:2531.

25. Aiba M, Hirayama A, Iri H, Ito $Y$, Fujimoto $Y$, Mabuchi G, et al. Adrenocorticotropic hormone-independent bilateral adrenocortical macronodular hyperplasia as a distinct subtype of Cushing's syndrome. Enzyme histochemical and ultrastructural study of four cases with a review of the literature. Am J Clin Pathol 1991;96:334-40.

26. Sasano H, Suzuki T, Nagura H. ACTH-independent macronodular adrenocortical hyperplasia: immunohistochemical and in situ hybridization studies of steroidogenic enzymes. Mod Pathol 1994;7:215-9.

27. Cugini P, Battisti P, Di Palma L, Sepe M, Kawasaki T, Uezono $\mathrm{K}$, et al. "GIANT" macronodular adrenal hyperplasia causing Cushing's syndrome: case report and review of the literature on a clinical distinction of adrenocortical nodular pathology associated with hypercortisolism. Endocrinol Jpn 1989;36: 101-16.

28. Aiba M, Kawakami M, Ito $Y$, Fujimoto $Y$, Suda T, Demura H. Bilateral adrenocortical adenomas causing Cushing's syndrome. Report of two cases with enzyme histochemical and ultrastructural studies and a review of the literature. Arch Pathol Lab Med 1992;116:146-50.

29. Schorr I, Ney RL. Abnormal hormone responses of an adrenocortical cancer adenyl cyclase. J Clin Invest 1971;50:1295-300.
30. Lacroix A, Baldacchino V, Bourdeau I, Hamet P, Tremblay J. Cushing's syndrome variants secondary to aberrant hormone receptors. Trends Endocrinol Metab 2004;15:375-82.

31. Hamet $P$, Larochelle $P$, Franks DJ, Cartier $P$, Bolte E. Cushing syndrome with food-dependent periodic hormonogenesis. Clin Invest Med 1987;10:530-3.

32. Lacroix A, Bolte E, Tremblay J, Dupre J, Poitras P, Fournier H, et al. Gastric inhibitory polypeptide-dependent cortisol hypersecretion - a new cause of Cushing's syndrome. N Engl J Med 1992;327:974-80.

33. Reznik Y, Allali-Zerah V, Chayvialle JA, Leroyer R, Leymarie P, Travert G, et al. Food-dependent Cushing's syndrome mediated by aberrant adrenal sensitivity to gastric inhibitory polypeptide. N Engl J Med 1992;327:981-6.

34. Lebrethon MC, Avallet O, Reznik Y, Archambeaud F, Combes $\mathrm{J}$, Usdin TB, et al. Food-dependent Cushing's syndrome: characterization and functional role of gastric inhibitory polypeptide receptor in the adrenals of three patients. J Clin Endocrinol Metab 1998;83:4514-9.

35. N'Diaye N, Tremblay J, Hamet P, De Herder WW, Lacroix A. Adrenocortical overexpression of gastric inhibitory polypeptide receptor underlies food-dependent Cushing's syndrome. J Clin Endocrinol Metab 1998;83:2781-5.

36. Groussin L, Perlemoine K, Contesse V, Lefebvre H, Tabarin A, Thieblot $P$, et al. The ectopic expression of the gastric inhibitory polypeptide receptor is frequent in adrenocorticotropin-independent bilateral macronodular adrenal hyperplasia, but rare in unilateral tumors. J Clin Endocrinol Metab 2002;87:1980-5.

37. Costa MHS, Lampron A, Godbout A, Ste-Marie LG, Bourdeau I, Lacroix A. In vivo screening for aberrant hormone responsiveness in primary aldosteronism. Program of the 89th Annual Meeting of the Endocrine Society, Toronto, CA, 2007, p. 198 (Abstract P1-163).

38. Chabre O, Liakos P, Vivier J, Chaffanjon P, Labat-Moleur F, Martinie $M$, et al. Cushing's syndrome due to a gastric inhibitory polypeptide-dependent adrenal adenoma: insights into hormonal control of adrenocortical tumorigenesis. J Clin Endocrinol Metab 1998;83:3134-43.

39. Swords FM, Aylwin S, Perry L, Arola J, Grossman AB, Monson JP, et al. The aberrant expression of the gastric inhibitory polypeptide (GIP) receptor in adrenal hyperplasia: does chronic adrenocorticotropin exposure stimulate up-regulation of GIP receptors in Cushing's disease? J Clin Endocrinol Metab 2005;90:3009-16.

40. Baldacchino V, Oble S, Decarie PO, Bourdeau I, Hamet P, Tremblay $\mathrm{J}$, et al. The $\mathrm{Sp}$ transcription factors are involved in the cellular expression of the human glucose-dependent insulinotropic polypeptide receptor gene and overexpressed in adrenals of patients with Cushing's syndrome. J Mol Endocrinol 2005;35:61-71.

41. Lampron A, Bourdeau I, Hamet P, Tremblay J, Lacroix A. Whole genome expression profiling of glucose-dependent insulinotropic peptide (GIP)- and adrenocorticotropin-dependent adrenal hyperplasias reveals novel targets for the study of GIP-dependent Cushing's syndrome. J Clin Endocrinol Metab 2006;91:3611-8.

42. Lacroix A, Tremblay J, Rousseau G, Bouvier M, Hamet P. Propranolol therapy for ectopic beta-adrenergic receptors in adrenal Cushing's syndrome. N Engl J Med 1997;337:1429-34.

43. Arnaldi G, Gasc JM, de Keyzer Y, Raffin-Sanson ML, Perraudin $\mathrm{V}$, Kuhn JM, et al. Variable expression of the V1 vasopressin receptor modulates the phenotypic response of steroid-secreting adrenocortical tumors. J Clin Endocrinol Metab 1998;83:2029-35.

44. Mircescu H, Jilwan J, N'Diaye N, Bourdeau I, Tremblay J, Hamet $P$, et al. Are ectopic or abnormal membrane hormone receptors frequently present in adrenal Cushing's syndrome? J Clin Endocrinol Metab 2000;85:3531-6.

45. Mune T, Murase H, Yamakita N, Fukuda T, Murayama M, Miura $A$, et al. Eutopic overexpression of vasopressin v1a receptor in adrenocorticotropin-independent macronodular adrenal hyperplasia. J Clin Endocrinol Metab 2002;87: 5706-13. 
46. Perraudin V, Delarue C, De Keyzer Y, Bertagna X, Kuhn JM, Contesse V, et al. Vasopressin-responsive adrenocortical tumor in a mild Cushing's syndrome: in vivo and in vitro studies. J Clin Endocrinol Metab 1995;80:2661-7.

47. Lee S, Hwang R, Lee J, Rhee Y, Kim DJ, Chung Ul, et al. Ectopic expression of vasopressin $\mathrm{V} 1 \mathrm{~b}$ and $\mathrm{V} 2$ receptors in the adrenal glands of familial ACTH-independent macronodular adrenal hyperplasia. Clin Endocrinol (Oxf) 2005;63:625-30.

48. Vezzosi D, Cartier D, Regnier C, Otal P, Bennet A, Parmentier $F$, et al. Familial adrenocorticotropin-independent macronodular adrenal hyperplasia with aberrant serotonin and vasopressin adrenal receptors. Eur J Endocrinol 2007; 156:21-31.

49. Miyamura N, Taguchi T, Murata Y, Taketa K, Iwashita S, Matsumoto K, et al. Inherited adrenocorticotropin-independent macronodular adrenal hyperplasia with abnormal cortisol secretion by vasopressin and catecholamines: detection of the aberrant hormone receptors on adrenal gland. Endocrine 2002;19:319-26.

50. Miyamura N, Tsutsumi A, Senokuchi H, Nakamaru K, Kawashima J, Sakai K, et al. A case of ACTH-independent macronodular adrenal hyperplasia: simultaneous expression of several aberrant hormone receptors in the adrenal gland. Endocr J 2003;50:333-40.

51. Ascoli M, Fanelli F, Segaloff DL. The lutropin/choriogonadotropin receptor, a 2002 perspective. Endocr Rev 2002;23:141-74.

52. Abdallah MA, Lei ZM, Li X, Greenwold N, Nakajima ST, Jauniaux $E$, et al. Human fetal nongonadal tissues contain human chorionic gonadotropin/luteinizing hormone receptors. J Clin Endocrinol Metab 2004;89:952-6.

53. Pabon JE, Li X, Lei ZM, Sanfilippo JS, Yussman MA, Rao CV. Novel presence of luteinizing hormone/chorionic gonadotropin receptors in human adrenal glands. J Clin Endocrinol Metab 1996;81:2397-400.

54. Coulter CL. Fetal adrenal development: insight gained from adrenal tumors. Trends Endocrinol Metab 2005;16:23542.

55. Lacroix A, Hamet $P$, Boutin JM. Leuprolide acetate therapy in luteinizing hormone-dependent Cushing's syndrome. N Engl J Med 1999;341:1577-81.

56. Feelders RA, Lamberts SW, Hofland LJ, van Koetsveld PM, Verhoef-Post $M$, Themmen AP, et al. Luteinizing hormone (LH)-responsive Cushing's syndrome: the demonstration of LH receptor messenger ribonucleic acid in hyperplastic adrenal cells, which respond to chorionic gonadotropin and serotonin agonists in vitro. J Clin Endocrinol Metab 2003;88:230-7.

57. Bertherat J, Contesse V, Louiset E, Barrande G, Duparc C, Groussin L, et al. In vivo and in vitro screening for illegitimate receptors in adrenocorticotropin-independent macronodular adrenal hyperplasia causing Cushing's syndrome: identification of two cases of gonadotropin/gastric inhibitory polypeptide-dependent hypercortisolism. J Clin Endocrinol Metab 2005;90:1302-10.

58. Cartier D, Lihrmann I, Parmentier F, Bastard C, Bertherat J, Caron $\mathrm{P}$, et al. Overexpression of serotonin4 receptors in cisapride-responsive adrenocorticotropin-independent bilateral macronodular adrenal hyperplasia causing Cushing's syndrome. J Clin Endocrinol Metab 2003;88:24854.

59. Mannelli M, Ferruzzi $P$, Luciani $P$, Crescioli $C$, Buci L, Corona $\mathrm{G}$, et al. Cushing's syndrome in a patient with bilateral macronodular adrenal hyperplasia responding to cisapride: an in vivo and in vitro study. J Clin Endocrinol Metab 2003;88:4616-22.

60. Louiset E, Contesse V, Groussin L, Cartier D, Duparc C, Barrande $\mathrm{G}$, et al. Expression of serotonin7 receptor and coupling of ectopic receptors to protein kinase $A$ and ionic currents in adrenocorticotropin-independent macronodular adrenal hyperplasia causing Cushing's syndrome. J Clin Endocrinol Metab 2006;91:4578-86.
61. Nakamura $Y$, Son $Y$, Kohno $Y$, Shimono D, Kuwamura N, Koshiyama $\mathrm{H}$, et al. Case of adrenocorticotropic hormoneindependent macronodular adrenal hyperplasia with possible adrenal hypersensitivity to angiotensin II. Endocrine 2001;15:57-61.

62. Slieker LJ, Sloop KW, Surface PL, Kriauciunas A, LaQuier F, Manetta $\mathrm{J}$, et al. Regulation of expression of ob mRNA and protein by glucocorticoids and cAMP. J Biol Chem 1996;271:5301-4.

63. Pralong FP, Roduit R, Waeber G, Castillo E, Mosimann F, Thorens $B$, et al. Leptin inhibits directly glucocorticoid secretion by normal human and rat adrenal gland. Endocrinology 1998; $139: 4264-8$.

64. Glasow A, Bornstein SR, Chrousos GP, Brown JW, Scherbaum WA. Detection of Ob-receptor in human adrenal neoplasms and effect of leptin on adrenal cell proliferation. Horm Metab Res 1999;31:247-51.

65. Pralong FP, Gomez F, Guillou L, Mosimann F, Franscella S, Gaillard RC. Food-dependent Cushing's syndrome: possible involvement of leptin in cortisol hypersecretion. J Clin Endocrinol Metab 1999;84:3817-22.

66. Hashimoto K, Kawada Y, Murakami K, Hattori T, Suemaru S, Kageyama J, et al. Cortisol responsiveness to insulin-induced hypoglycemia in Cushing's syndrome with huge nodular adrenocortical hyperplasia. Endocrinol Jpn 1986;33:479-87.

67. Makino S, Hashimoto K, Sugiyama M, Hirasawa R, Takao T, Ota Z, et al. Cushing's syndrome due to huge nodular adrenocortical hyperplasia with fluctuation of urinary $17-\mathrm{OHCS}$ excretion. Endocrinol Jpn 1989;36:655-63.

68. Willenberg HS, Stratakis CA, Marx C, Ehrhart-Bornstein M, Chrousos GP, Bornstein SR. Aberrant interleukin-1 receptors in a cortisol-secreting adrenal adenoma causing Cushing's syndrome. N Engl J Med 1998;339:27-31.

69. Antonini SR, N'Diaye N, Hamet P, Tremblay J, Lacroix A. Analysis of the putative promoter region of the GIP receptor gene (GIPR) in GIP-dependent Cushing's syndrome (CS). Endocr Res 2002;28:755-6.

70. Antonini SR, N'Diaye N, Baldacchino V, Hamet P, Tremblay J, Lacroix $A$. Analysis of the putative regulatory region of the gastric inhibitory polypeptide receptor gene in food-dependent Cushing's syndrome. J Steroid Biochem Mol Biol 2004;91:171-7.

71. Bourdeau I, Antonini SR, Lacroix A, Kirschner LS, Matyakhina $L$, Lorang $D$, et al. Gene array analysis of macronodular adrenal hyperplasia confirms clinical heterogeneity and identifies several candidate genes as molecular mediators. Oncogene 2004:23:1575-85.

72. Bourdeau I, Boisselle A, Rioux D, Neculau M, Hamet $P$, Lacroix A. Systematic clinical screening of members of a family with hereditary cortisol-secreting B-adrenergic responsive ACTH-Independent Macronodular Adrenal Hyperplasia (AIMAH) reveals unsuspected subclinical Cushing's syndrome (CS) and aberrant B-adrenergic regulation of cortisol secretion. Program of the 89th Annual Meeting of the Endocrine Society, Toronto, CA, 2007, p. 148 (Abstract OR54-2).

73. Mazzuco TL, Chabre O, Feige JJ, Thomas M. Aberrant expression of human luteinizing hormone receptor by adrenocortical cells is sufficient to provoke both hyperplasia and Cushing's syndrome features. J Clin Endocrinol Metab 2006;91:196-203.

74. Mazzuco TL, Chabre O, Sturm N, Feige JJ, Thomas M. Ectopic expression of the gastric inhibitory polypeptide receptor gene is a sufficient genetic event to induce benign adrenocortical tumor in a xenotransplantation model. Endocrinology 2006; $147: 782-90$.

75. Mazzuco TL, Chabre O, Feige JJ, Thomas M. Aberrant GPCR expression is a sufficient genetic event to trigger adrenocortical tumorigenesis. Mol Cell Endocrinol 2007;265-266:23-8.

76. Lacroix AM, Hammet PH. Clinical evaluation of the presence of abnormal hormone receptors in adrenal Cushing's syndrome. Endocrinologist 1999;9:9-15. 
77. Reznik Y, Lefebvre H, Rohmer V, Charbonnel B, Tabarin A, Rodien $\mathrm{P}$, et al. Aberrant adrenal sensitivity to multiple ligands in unilateral incidentaloma with subclinical autonomous cortisol hypersecretion: a prospective clinical study. Clin Endocrinol (Oxf) 2004;61:311-9.

78. Matyakhina L, Freedman RJ, Bourdeau I, Wei MH, Stergiopoulos SG, Chidakel A, et al. Hereditary leiomyomatosis associated with bilateral, massive, macronodular adrenocortical disease and atypical Cushing syndrome: a clinical and molecular genetic investigation. J Clin Endocrinol Metab 2005;90:3773-9.

79. Bourdeau I, Matyakhina L, Stergiopoulos SG, Sandrini F, Boikos S, Stratakis CA. 17q22-24 chromosomal losses and alterations of protein kinase a subunit expression and activity in adrenocorticotropin-independent macronodular adrenal hyperplasia. J Clin Endocrinol Metab 2006;91:3626-32.

80. Fragoso MC, Domenice S, Latronico AC, Martin RM, Pereira $M A$, Zerbini MC, et al. Cushing's syndrome secondary to adrenocorticotropin-independent macronodular adrenocortical hyperplasia due to activating mutations of GNAS1 gene. J Clin Endocrinol Metab 2003;88:2147-51.

81. Swords FM, Baig A, Malchoff DM, Malchoff CD, Thorner MO, King PJ, et al. Impaired desensitization of a mutant adrenocorticotropin receptor associated with apparent constitutive activity. Mol Endocrinol 2002;16:2746-53.

82. Swords FM, Noon LA, King PJ, Clark AJ. Constitutive activation of the human ACTH receptor resulting from a synergistic interaction between two naturally occurring missense mutations in the MC2R gene. Mol Cell Endocrinol 2004; $213: 149-54$.

83. Imohl M, Koditz R, Stachon A, Muller KM, Nicolas $V$, Pfeilschifter J, et al. [Catecholamine-dependent hereditary Cushing's syndrome - follow-up after unilateral adrenalectomy]. Med Klin (Munich) 2002;97:747-53.
84. Lefebvre H, Duparc C, Chartrel N, Jegou S, Pellerin A, Laquerriere $\mathrm{A}$, et al. Intraadrenal adrenocorticotropin production in a case of bilateral macronodular adrenal hyperplasia causing Cushing's syndrome. J Clin Endocrinol Metab 2003;88:3035-42.

85. Boronat M, Lucas T, Barcelo B, Alameda C, Hotait H, Estrada J. Cushing's syndrome due to autonomous macronodular adrenal hyperplasia: long-term follow-up after unilateral adrenalectomy. Postgrad Med J 1996;72:614-6.

86. Lamas C, Alfaro JJ, Lucas T, Lecumberri B, Barcelo B, Estrada J. Is unilateral adrenalectomy an alternative treatment for ACTH-independent macronodular adrenal hyperplasia? Long-term follow-up of four cases. Eur J Endocrinol 2002;146:237-40.

87. Herder WW, Hofland LJ, Usdin TB, de Jong FH, Uitterlinden $P$, van Koetsveld $P$, et al. Food-dependent Cushing's syndrome resulting from abundant expression of gastric inhibitory polypeptide receptors in adrenal adenoma cells. J Clin Endocrinol Metab 1996;81:3168-72.

Address for correspondence:

André Lacroix

Hôtel-Dieu du CHUM

3840 Saint-Urbain street

Montréal, Québec

Canada H2W 1 T8

Fax: (514) 412-7128

E-mail: andre.lacroix@umontreal.ca 